\title{
MENINGKATAN KREATIVITAS SENI MELALUI PERMAINAN BAK PASIR UNTUK ANAK KELOMPOK A DI RA AL-ISHLAH KALIPARE-MALANG
}

\author{
Rima Azizatul Laila ${ }^{1}$, Nuryahati ${ }^{2}$ \\ Program Studi Pendidikan Islam Anak Usia Dini,Fakultas Tarbiyah, \\ Institut Agama Islam Al-Qolam Malang \\ nurhayati@alqolam.ac.id
}

\begin{tabular}{l}
\hline Info Artikel \\
\hline Riwayat Artikel \\
Diterima : \\
1 September 2019 \\
Disetujui : \\
30 September 2019 \\
\end{tabular}

Kata Kunci :

Kreativitas Seni,

Permainan Bak Pasir

\begin{abstract}
The increased children's creativity begins with activities that are easily carried out in accordance with the level of difficulty gradually. This study aims to describe the development of children's artistic creativity through sandbox games in group A children in RA Al-Ishlah Kalipare and to describe the application of sandbox games that enhance artistic creativity in group A children in RA Al-Ishlah Kalipare. The classroom action research method (Action Research) applies two cycles. Data collection techniques include interviews, observation and documentation. The results of the study in the first cycle showed that children's artistic creativity has increased after taking action with a percentage of $37.49 \%$. However, the increase in children's creativity has not yet reached the expected success indicator so that it needs to be improved in the second cycle with a percentage of $85.71 \%$ an increase including a percentage of $48.22 \%$ including high criteria. this research can be concluded that the process of children's creativity through sandbox games is very suitable for use in the process of early childhood learning.
\end{abstract}

Abstrak: Peningkatan kreativitas anak di awali dari kegiatan yang mudah dilakukan sesuai dengan tingkat kesulitas secara bertahap. Penelitian ini bertujuan untuk mendeskripsikan perkembangan kreativitas seni anak melalui permainan bak pasir pada anak kelompok A di RA Al-Ishlah Kalipare dan untuk mendeskripsikan penerapan permainan bak pasir yang meningkatan kreativitas seni pada anak kelompok A di RA AlIshlah Kalipare. Metode penelitian tindakan kelas (Action Research) menerapkan dua siklus. Teknik pengumpulan data meliputi wawancara, observasi dan dokumentasi. Hasil penelitian pada siklus I menunjukkan kreativitas seni anak sudah mengalami peningkatan setelah dilakukan tindakan dengan prosentase $37,49 \%$. Akan tetapi peningkatan kreativitas anak belum mencapai indikator keberhasilan yang diharapkan sehingga perlu perbaikan pada siklus II dengan prosentase $85,71 \%$ terjadi peningkatan diantaranya dengan prosentase $48,22 \%$ termasuk kriteria tinggi. penelitian ini dapat disimpulkan proses kreativitas anak melalui permainan bak pasir sangat cocok digunakan dalam proses pembelajaran anak usia dini. 


\section{PENDAHULUAN}

Pendidikan anak usia dini adalah masa awal dimana perkembangan dan pertumbuhan sangat berarti dalam sebuah kehidupan. Masa ini terdapat suatu periode yaitu periode keemasan, yang setiap orang akan mengalaminya secara perorangan dari kandungan hingga meninggal dunia. ${ }^{1}$ AUD juga dimaknai sebagai anak prasekolah, mempunyai masa yang cocok untuk meletakkan dasar pertama dalam semua aspek perkembangan yakni kognitif, fisik, bahasa, seni, sosial emosional, spiritual, disiplin diri, kemandirian serta pengembangan kreativitas anak.

Kemampuan yang patut ditumbuh kembangkan mulai dini pada diri anak adalah kreativitasnya. Sedangkan seni ialah sebuah rangsangan dari kreatif. Artinya pembelajaran yang mengikutsertakan seni di dalamnya akan lebih banyak menghidupkan tempat-tempat pada otak ketimbang tidak mengikutsertakan seni dalam pembelajaran. Kemampuan kreatif dimiliki oleh setiap anak, namun dalam kadar yang berbeda dan harus dikembangkan sejak usia dini agar kemampuan yang dimiliki dapat berkembang dengan optimal. ${ }^{2}$ Maka dari itu, diperlukan upaya-upaya untuk mengembangkan kreativitas pada anak. Banyak hal yang dapat dipakai untuk menampilkan kreativitas pada anak misalnya dalam bentuk gambar, cerita, bermain peran atau dengan karya seni lainnya. Tetapi terdapat kendala dalam mengembangkan kreativitas pada anak yaitu dari orang tua dan pendidik yang memiliki pandangan bahwa kecerdasan anak hanya diukur dari cerdasnya anak dalam bidang akademik.

Permasalahan kecerdasan anak dalam bidang akademik seperti baca tulis dan berhitung. Masalah ini terjadi di kelompok A, sehingga terlihat jelas rendahnya kreativitas serta seni pada anak. Hal ini tampak saat pembelajaran di RA pendidik memberikan tugas ketrampilan atau karya seni dalam bentuk apapun anak belum mampu mencapai empat aspek kreativitas antara lain, fluency/ kelancaran, flexibility/ keluwesan, originality/ keaslian, elaboration/ keterperincian. ${ }^{3}$ Dari 14 siswa yang ada di kelompok A hanya 2 anak yang mampu mencapai 4 aspek kreativitas dan bisa berkreasi serta berimajinasi sesuai dengan keinginan mereka. Sedangkan 12 anak belum mampu mencapai 4 aspek kreativitas dan hanya mencontoh dari karya yang sudah ada atau dari pendidik dan teman tanpa mencoba sesuai imajinasi yang mereka punya. Padahal imajinasi untuk anak-anak merupakan kebutuhan alamiah dan bukan kemalasan. Selain itu pembelajaran yang dilaksanakan di RA kurang beragam atau terbatas sehingga anak merasa tidak tertarik dan enggan mengikuti pembelajaran dengan baik. Terutama saat pembelajaran seni, dimana anak seharusnya dapat bereksplorasi sesuai dengan kreativitas serta imajinasi yang dimiliki. Tetapi dengan tidak tertariknya anak dalam pembelajaran membuat anak tidak bersemangat dan menghambat proses

${ }^{1}$ Fadilillah, M (2017). Bermain dan Permainan. Cetakan I. Jakarta: Kencana.

${ }^{2}$ Hurlock, Elizabeth., B. (1989). Perkembangan Anak. Jilid I. Jakarta: Erlangga.

${ }^{3}$ Kustandi, C., (2013). Media Pembelajaran Manusia dan Digital. Bogor: Ghali Indonesia. 
kreativitasnya. Anak cenderung bermain sendiri sesuai yang mereka inginkan dan tidak mengikuti aturan pembelajaran yang sudah dirancang oleh guru. Padahal waktu anak didik melakukan suatu kegiatan yang mereka senangi mereka akan melakukannya dengan optimal, sehingga hasil karya yang mereka buat dapat meningkatkan kreativitas anak.

Berdasarkan penjelasan di atas dapat diketahui bahwa kreativitas anak masih sangat rendah dan membutuhkan stimulasi atau rangsangan untuk meningkatkan kemampuan kreativitas seni pada anak dengan cara memberikan pembelajaran yang bervariasi dan menyenangkan, agar anak merasa bersemangat dalam pembelajaran serta imajinasi anak dapat terwujudkan dalam karya seni. Sehingga dapat menunjang proses awal tumbuh kembangnya dan bermanfaat bagi perkembangan pribadinya.

kreativitas merupakan suatu proses "mental" individu yang melahirkan ide, konsep, gagasan, bahkan produk yang baru yang tidak terpikirkan oleh orang lain pada umumnya yang mempunyai nilai kemanfaatan dalam memecahkan suatu permasalahan. Kemampuan kreatif sejatinya adalah kemampuan yang dimiliki oleh setiap manusia, hanya saja kadarnya yang berbeda antara manusia satu dengan yang lain. Model pengembangan kreativitas dalam munandar, yaitu model Rhodes yang dikenal dengan istilah the four $P$ 's of creativity, yang meliputi pribadi (person), proses (process), hasil (product), dan pendorong (press). ${ }^{4}$ Pengembangan dari aspek pribadi ini adalah ungkapan keunikan individu dalam interaksi dengan lingkungan. Dari pribadi yang unik inilah diharapkan timbul ide-ide baru dan produk-produk yang inovatif. Perkembangan kreativitas dari aspek process adalah dalam mengembangkan kreativitas anak, ia perlu diberi kesempatan untuk bersibuk secara aktif. Pendidik hendaknya dapat merangsang anak untuk melibatkan dirinya dalam berbagai kegiatan kreatif. Pengembangan kreatif dari aspek product adalah kondisi yang memungkinkan seseorang menciptakan produk kreatif yang bermakna adalah kondisi pribadi dan lingkungan yaitu sejauh mana keduanya mendorong seseorang untuk melibatkan dirinya dalam proses (kesibukan dan kegiatan) kreatif. Hal yang tidak boleh dilupakan bahwa pendidik menghargai produk kreativitas anak dan mengkomunikasikannya kepada yang lain, seperti dengan mempertunjukkan atau memperlihatkan hasil karya anak. Ini akan lebih menggugah minat anak untuk berkreasi. Pengembangan kreativitas dari aspek press adalah bahwa untuk mewujudkan bakat kreatif anak diperlukan dorongan dan dukungan dari lingkungan (motivasi eksternal) yang berupa apresiasi, dukungan, pemberian penghargaan, pujian, dan dorongan dari dalam diri anak sendiri (motivasi internal) untuk menghasilkan sesuatu.

Bermain adalah serangkaian kegiatan atau aktivitas anak untuk bersenangsenang. Apapun kegiatannya, selama itu terdapat unsur kesenangan atau

\footnotetext{
${ }^{4}$ Mulyani, Novi (2017). Pengembangan Seni Anak Usia Dini. Bandung: PT. Remaja Rosdakarya 
kebahagian bagi anak usia dini, maka disebut sebagai bermain. ${ }^{5}$ Menurut Johnson, dkk. Mengemukakan, bahwa bermain merupakan cara anak belajar tentang diri sendiri dan dunia dimana mereka berada. Sedangkan menurut Bettleheim, kegiatan bermain adalah kegiatan yang tidak mempunyai peraturan lain kecuali yang ditetapkan pemain itu sendiri dan tidak ada hasil akhir.

Bak Pasir merupakan alat permainan edukatif yang terbuat dari papan yang dibentuk menyerupai bak, kemudian di dalamnya diisi dengan pasir sampai penuh. Alat permainan bak pasir ini adalah kategori alat bermain bebas. Jadi dalam penggunaannya pun anak bebas berkreativitas sesuai imajinasinya. Hampir semua kegiatan di RA bisa memotifasi anak untuk memperoleh percobaan dan kreatif. Salah satu contohnya adalah dengan mengenalkan anak dengan kreativitas seni menggunakan permainan bak pasir. Pembelajaran seni di RA harus sejalan dengan hakekat dan fungsi seni sebagai alat pendidikan adalah dengan mempertimbangkan aspek edukatif, psikologis, karakteristik materi dan ketersediaan sumber belajar.

Pembelajaran seni dapat diajarkan dengan cara bermain, memperkenalkan sebuah masa "bekerja-bermain" di mana anak-anak dengan bebasnya mengeksplorasi benda-benda serta alat-alat bemain yang ada dilingkungannya, serta melaksanakan ide-ide mereka sendiri. Dengan permainan bak pasir ini, anak belajar mengenal bahan dari alam, dalam penerapan permainannya anak dapat belajar meremas, mengisi cetakan hingga penuh dan padat, memilih bentuk cetakan yang diinginkan serta mencoba berbagai bentuk yang bervariasi menggunakan cetakan. Sehingga anak dapat belajar mengembangkan kreativitasnya dengan cara mengeksplorasikan ide-idenya melalui bentuk-bentuk yang diinginkan menggunakan cetakan yang telah disediakan.

Manfaat permainan bak pasir, meliputi pertama, untuk mengembangkan kreativitas seni anak karena dalam permainan bak pasir terdapat pembelajaran yang mengarah pada karya seni berupa pembelajaran mencetak. Kedua, Anak dapat mengembangkan pengetahuannya tentang alam sekitar melalui bahan permainan seperti pasir serta alat yang digunakan pada beberapa cetakan yang berbentuk hewan dan bentuk lainnya. Ketiga, Anak dapat mengeksplorasi ide-ide kreatifnya menggunakan permainan bak pasir. Empat, Anak dapat berimajinasi melalui bentuk-bentuk pada cetakan sehingga menjadi suatu bentuk kreatif yang anak inginkan. Kelima, Pembelajaran akan lebih menyenangkan dan lebih efektif karena bahan yang digunakan sudah dikenal anak sehingga anak dapat menerima dan menguasai dengan baik. Keenam, Anak usia 4 tahun senang untuk bermain pasir karena anak berada pada masa kepekaan untuk mempelajari suara dan memperbaiki indra sentuhnya. 7) Dapat menstimulus anak untuk belajar merespon, menerima, dan memberi serta menolak dan setuju dengan ide orang lain. Hal ini akan mengurangi egosentris anak.

\footnotetext{
${ }^{5}$ Fadilillah, M (2017). Bermain dan Permainan. Cetakan I. Jakarta: Kencana
} 
Tujuan penelitian ini meliputi untuk mendeskripsikan peningkatan kreativitas seni anak melalui permainan bak pasir pada anak kelompok A di RA Al-Ishlah Kalipare dan untuk mendeskripsikan penerapan permainan bak pasir yang meningkatan kreativitas seni pada anak kelompok A di RA Al-Ishlah Kalipare.

\section{METODE}

Penelitian ini menggunakan jenis Penelitian Tindakan Kelas (action research). Menurut Suharsimi Arikunto yang dikutip oleh kusumah, 2011 membahas tentang Penelitian Tindakan Kelas (PTK) terdiri dari penelitian, tindakan, dan kelas. Dari ketiga unsur pengertian tersebut, dapat disimpulkan yang dimaksud dengan Penelitian Tindakan Kelas (PTK) adalah pencermatan dalam bentuk tindakan terhadap kegiatan belajar yang sengata dimunculkan dan terjadi dalam sebuah kelas secara bersamaan. ${ }^{6}$ Beberapa model desain Penelitian Tindakan Kelas (PTK) yang dikemukakan oleh para ahli secara global terdiri atas empat komponen, yaitu perencanaan, pelaksanaan tindakan, observasi, dan refleksi.

Penelitian tindakan kelas ini dilakukan di kelompok A RA Al-Ishlah Kalipare Kecamatan Kalipare Malang. Penelitian ini dilakukan pada semester II tahun pelajaran 2018/2019. Dalam penelitian ini subyek penelitian adalah kelompok A RA Al-Ishlah Kalipare Kecamatan Kalipare Malang yang berusia 4-5 tahun. Jumlah anak kelompok A adalah 14 anak yang terdiri dari 5 anak perempuan dan 9 anak laki-laki. Obyek dalam penelitian ini adalah meningkatkan kreativitas seni menggunakan permainan bak pasir.

Instrumen yang dipergunakan untuk melakukan observasi dalam meningkatkan kreativitas menggunakan permainan bak pasir pada anak kelompok A RA Al-Ishlah Kalipare Kecamatan Kalipare Kabupaten Malang adalah berupa lembar observasi. Data dari observasi tersebut direkapitulasi hasil pencapaian kemampuan anak dalam membuat berbagai macam bentuk yang anak suka melalui permainan bak pasir.

Pada penelitian tindakan kelas ini penulis menggunakan metode observasi dan dokumentasi dalam pengumpulan data. Penelitian ini memakai teknik analisis deskriptif kualitatif dan kuantitatif. Kualitatif yakni data yang digunakan berupa kalimat yang dipergunakan untuk mendapatkan informasi yang jelas dan mendetail sedangkan kuantitatif yaitu data yang berupa bilangan, nilainya dapat berubah-ubah atau bersifat variatif. Tindakan dalam penelitian ini dikatakan berhasil apabila dalam kegiatan bermain bak pasir 75\% dari 14 anak usia 4-5 tahun di RA Al-Ishlah Kalipare mengalami peningkatan kreativitas seni Berkembang Sesuai Harapan (BSH).

\footnotetext{
${ }^{6}$ Kusumah, Wijaya dan Dedi Dwitagama. (2011). Mengenal Penelitian Tindakan Kelas. Jakarta: Indeks.
} 


\section{HASIL DAN PEMBAHASAN}

Sebelum melaksanakan penelitian dilakukan observasi terlebih dahulu pada kreativitas seni anak melalui kegiatan pembelajaran keseharian anak tanpa menganggu pembelajaran yang berlangsung, untuk mengetahui perkembangan kreativitas seni anak. Peneliti menilai aktivitas belajar anak yang berkaitan dengan kreativitas seni menggunakan instrumen lembar observasi berbentuk checklist.

Kegiatan pembelajaran yang berhubungan dengan kreativitas seni yang dilakukan oleh guru kelas yaitu pemberian tugas menggambar macam-macam benda. Guru memberi contoh cara mengerjakan tugas tersebut dengan menggambar pohon. Anak mengerjakan tugas dengan menggambar benda sesuai dengan ide dan keinginan anak. Pada penerapan kegiatan tersebut, kemampuan dan perkembangan anak dalam kreativitas seni masih rendah belum dikatakan baik. Anak masih bergantung kepada guru dalam pembelajaran. Metode yang digunakan masih menggunakan model klasikal, dimana pembelajaran terpusat pada guru dan anak hanya mengikuti apa yang telah dicontohkan oleh guru sehingga kreativitas anak kurang berkembang. Deskripsi tindakan dan hasilnya diuraikan sebagai berikut.

Perencanaan tindakan meliputi: 1) Penyusunan rencana pelaksanaan pembelajaran harian (RPPH), yang dakan dipakai dalam kegiatan pembelajaran dalam satu hari bersama guru kelas. 2) Tema yang dipakai adalah "Alam Semesta". 3) Menyusun dan mempersiapkan lembar observasi dalam setiap pertemuan untuk mengetahui kreativitas seni anak menggunakan permainan bak pasir. 4) Menyusun dan menyiapkan alat dan bahan dalam permainan bak pasir yang akan digunakan saat penelitian. Dalam Penelitian ini berupa permainan bak pasir. 5) Menyiapkan kamera untuk mendokumentasikan kegiatan anak pada saat proses pembelajaran. Siklus I dilakukan sebanyak 4 kali pertemuan, yakni pada tanggal 8 April-11 April 2019.

Hasil penelitian menunjukkan bahwa ada peningkatan pada kemampuan kreativitas seni anak, hal ini dapat dilihat dari hasil observasi pada beberapa kegiatan mencetak pada permainan bak pasir yaitu: fluency/ kelancaran, flexibility/ keluwesan, originality/ keaslian, elaboration/ keterperincian dalam mencetak. Perkembangan rata-rata anak kelompok A dapat dilihat pada tabel 1, sebagai berikut:

Tabel 4.1. Hasil Observasi Keseluruhan Siklus I dalam meningkatkan kreativitas seni pada anak kelompok A melalui permainan Bak pasir. $^{7}$

\begin{tabular}{l}
\hline No Aspek yang diamati Rata-rata Indikator Keberhasilan \\
\hline $\begin{array}{l}{ }^{7} \text { Tabel 1. Hasil Observasi Keseluruhan Siklus I dalam meningkatkan kreativitas seni pada anak kelompok A } \\
\text { melalui permainan Bak pasir }\end{array}$
\end{tabular}




\begin{tabular}{clccc}
\hline & & M & TM & Ket \\
\hline $\mathbf{1}$ & fluency/ kelancaran & $50 \%$ & $50 \%$ & MB \\
\hline $\mathbf{2}$ & flexibility/ keluwesan & $35,71 \%$ & $64,28 \%$ & $\mathrm{BB}$ \\
\hline $\mathbf{3}$ & originality/ keaslian & $21,42 \%$ & $78,57 \%$ & $\mathrm{BB}$ \\
\hline $\mathbf{4}$ & elaboration/ keterperincian & $42,85 \%$ & $57,14 \%$ & $\mathrm{MB}$ \\
\hline & Rata-rata & $37,49 \%$ & $62,49 \%$ & $\mathrm{BB}$ \\
\hline
\end{tabular}

Berdasarkan paparan data pada tabel 4.1 diatas terlihat bahwa pada siklus I peningkatan kreativitas seni anak melalui permainan bak pasir pada variabel penelitian kreativitas seni dengan indikator fluency/ kelancaran mencapai nilai $50 \%$, flexibility/ keluwesan mencapai nilai 35,71\%, originality/keaslian mencapai $21,42 \%$ dan elaboration/ keterperincian mencapai $42,85 \%$. Sehingga nilai rata-rata kreativitas seni anak melalui permaianan bak pasir dengan variabel kreativitas seni secara keseluruhan adalah 37,49\%. Jadi kesimpulannya adalah kreativitas seni anak sudah mengalami peningkatan setelah dilakukan tindakan.

Hasil refleksi dari penelitian siklus I telah memperlihatkan adanya peningkatan dalam kreativitas seni anak. Hal ini tampak pada persentase yang dicapai pada aspek-aspek kreativitas anak. Dari kegiatan bermain bak pasir pada tindakan siklus I dapat disimpulkan bahwa perkembangan kreativitas anak mengalami peningkatan. Akan tetapi peningkatan kreativitas anak belum mencapai indikator keberhasilan yang diharapkan. Dengan demikian peneliti akan melanjutkan untuk melaksanakan tindakan pada siklus II.

Sebelum melakukan kegiatan pembelajaran pada siklus II disusun perencanaan terlebih dahulu. Perencanaan ini sama halnya dengan siklus I yang dibutuhkan antara lain: 1) Penyusunan rencana pelaksanaan pembelajaran harian (RPPH), yang dakan dipakai dalam kegiatan pembelajaran dalam satu hari bersama guru kelas. 2) Tema yang dipakai adalah "Alam Semesta". 3) Menyusun dan mempersiapkan lembar observasi dalam setiap pertemuan untuk mengetahui kreativitas seni anak menggunakan permainan bak pasir. 4) Menyusun dan menyiapkan alat dan bahan dalam permainan bak pasir yang akan digunakan saat penelitian. Dalam Penelitian ini berupa permainan bak pasir. 5) Menyiapkan kamera untuk mendokumentasikan kegiatan anak pada saat proses pembelajaran.

Hasil penelitian pada silus II menunjukkan adanya peningkatan pada kemampuan kreativitas seni anak kelompok A yang distimulasi dengan menggunakan permainan bak pasir. Perkembangan rata-rata anak kelompok A dapat dilihat pada tabel 4.2, sebagai berikut : 
Tabel 4.2. Hasil Observasi Keseluruhan Siklus II dalam meningkatkan kreativitas seni pada anak kelompok A melalui permainan Bak pasir. ${ }^{8}$

\begin{tabular}{ccccc}
\hline \multirow{2}{*}{ No } & \multirow{2}{*}{ Aspek yang diamati } & \multicolumn{3}{c}{ Rata-rata Indikator Keberhasilan } \\
\cline { 3 - 5 } & & $\mathbf{M}$ & TM & Ket \\
\hline $\mathbf{1}$ & fluency/ kelancaran & $92,85 \%$ & $7,14 \%$ & $\mathrm{BSB}$ \\
\hline $\mathbf{2}$ & flexibility/ keluwesan & $85,71 \%$ & $14,28 \%$ & $\mathrm{BSB}$ \\
\hline $\mathbf{3}$ & originality/ keaslian & $78,57 \%$ & $21,42 \%$ & $\mathrm{BSH}$ \\
\hline $\mathbf{4}$ & elaboration/ keterperincian & $85,71 \%$ & $14,28 \%$ & $\mathrm{BSB}$ \\
\hline \multicolumn{2}{c}{ Rata-rata } & $85,71 \%$ & $14,28 \%$ & $\mathrm{BSB}$ \\
\hline
\end{tabular}

Berdasarkan paparan data pada tabel 4.2 di atas terlihat bahwa pada siklus II dalam meningkatkan kreativitas seni melalui permainan bak pasir pada variabel penelitian kreativitas seni dengan indikator fluency/ kelancaran mencapai nilai $92,85 \%$, flexibility/ keluwesan mencapai nilai $85,71 \%$, originality/ keaslian mencapai $78,57 \%$ dan elaboration/ keterperincian mencapai $85,71 \%$. Sehingga nilai rata-rata kreativitas seni anak melalui permaianan bak pasir dengan variabel kreativitas seni secara keseluruhan adalah $85,71 \%$. Jadi kesimpulannya adalah kreativitas seni anak sudah mengalami peningkatan dan sesuai dengan indikator keberhasilan.

Berdasarkan penelitian yang dilakukan pada siklus II hasil proses pelaksanaan pembelajaran kreativitas seni melalui aktivitas bermain permaianan bak pasir pada siklus II menunjukkan peningkatan dibandingkan pada siklus I. Hal ini dapat dilihat dari perbandingan presentase hasil observasi dan penilaian secara keseluruhan kegiatan pembelajaran pada siklus I dan siklus II,sebagai berikut:

Tabel 4.3 Perbandingan Hasil Observasi Siklus I dan Siklus II dalam Meningkatan Kreativitas Seni pada anak kelompok A melalui permainan Bak Pasir ${ }^{9}$

\begin{tabular}{clccc}
\hline \multirow{2}{*}{ No } & \multirow{2}{*}{ Aspek yang diamati } & \multicolumn{3}{c}{ Rata-rata Indikator Keberhasilan } \\
\cline { 3 - 5 } & Siklus I & Siklus II & Peningkatan \\
\hline $\mathbf{1}$ & fluency/ kelancaran & $50 \%$ & $92,85 \%$ & $42,85 \%$ \\
\hline $\mathbf{2}$ & flexibility/ keluwesan & $35,71 \%$ & $85,71 \%$ & $50 \%$ \\
\hline $\mathbf{3}$ & originality/ keaslian & $21,42 \%$ & $78,57 \%$ & $57,15 \%$ \\
\hline $\mathbf{4}$ & $\begin{array}{l}\text { elaboration/ } \\
\text { keterperincian }\end{array}$ & $42,85 \%$ & $85,71 \%$ & $42,86 \%$ \\
\hline & Rata-rata & $37,49 \%$ & $85,71 \%$ & $48,21 \%$
\end{tabular}

Berdasarkan pada tabel 4.3 dapat dilihat bahwa adanya peningkatan dari siklus I dan siklus II. Presentase hasil observasi siklus I secara keseluruhan mencapai $37,49 \%$. Sedangkan presentase hasil observasi siklus II meningkat menjadi $85,71 \%$. Presentase hasil observasi pada siklus I dan siklus II mempunyai

\footnotetext{
${ }^{8}$ Tabel 2. Hasil Observasi Keseluruhan Siklus II dalam meningkatkan kreativitas seni pada anak kelompok A melalui permainan Bak pasir.

${ }^{9}$ Tabel 3 Perbandingan Hasil Observasi Siklus I dan Siklus II dalam Meningkatan Kreativitas Seni pada anak kelompok A melalui permainan Bak Pasir.
} 
selisih 48,21\%. Jadi persentase hasil observasi siklus I 37,49 \%, kemudian meningkat $48,21 \%$ pada siklus II menjadi $85,71 \%$.

Penerapan permainan bak pasir pada anak kelompok A di RA Al-Ishlah Kalipare Kecamatan Kalipare Kabupaten Malang pada siklus I sudah ada peningkatan pada anak tetapi belum mencapai indikator keberhasilan. Hal ini dapat dilihat dari indikator keberhasilan pada setiap kegiatan pembelajaran kreativitas seni anak. Maka peneliti melanjutkan kegiatan pembelajaran siklus II dengan melakukan kegiatan yang sama dan permainan yang sama namun pada penerapan permainan bak pasir anak benar-benar disuruh memilih dan memainkan permainan bak pasir sesuai keinginannya dan hasil cetakannya berdasarkan apa yang ada pada imajinasi anak masing-masing. Kegiatan ini dilakukan selama 4 hari atau 4 kali pertemuan. Setelah kegiatan siklus II sudah dilaksanakan terjadi peningkatan terhadap kreativitas anak yaitu pada kegiatan bermain permainan bak pasir. Jadi terdapat peningkatan pada kreativitas seni anak melalui kegiatan bermain permainan bak pasir pada anak kelompok A di RA Al-Ishlah Kalipare Kecamatan Kalipare Kabupaten Malang.

Berdasarkan hasil penelitian tersebut dan dari hasil observasi keseluruhan pada siklus I dan siklus II dapat meningkatkan kreativitas seni anak kelompok A di RA Al-Ishlah Kalipare melalui permainan bak pasir. Hal ini dapat dilihat dari pencapaian persentase keseluruhan yang dihitung pada siklus I 37,49\% pada siklus II meningkat dengan persentase $85,71 \%$.

\section{SIMPULAN DAN SARAN}

Hasil penelitian tentang meningkatkan kreativitas seni anak usia dini menggunakan permainan bak pasir kelompok A di RA Al-Ishlah Kalipare Kecamatan Kalipare Malang dapat disimpulkan sebagai berikut: 1) Setelah diterapkan permainan bak pasir pada anak kelompok A di RA Al-Ishlah Kalipare Kecamatan Kalipare Kabupaten Malang pada siklus I sudah ada peningkatan pada anak tetapi belum mencapai indikator keberhasilan. Hal ini dapat dilihat dari indikator keberhasilan pada setiap kegiatan pembelajaran kreativitas seni anak. Maka peneliti melanjutkan kegiatan pembelajaran siklus II dengan melakukan kegiatan yang sama dan permainan yang sama namun pada penerapan permainan bak pasir anak benar-benar disuruh memilih dan memainkan permainan bak pasir sesuai keinginannya dan hasil cetakannya berdasarkan apa yang ada pada imajinasi anak masing-masing. Kegiatan ini dilakukan selama 4 hari atau 4 kali pertemuan. Setelah kegiatan siklus II sudah dilaksanakan terjadi peningkatan terhadap kreativitas anak yaitu pada kegiatan bermain permainan bak pasir. Jadi terdapat peningkatan pada kreativitas seni anak melalui kegiatan bermain permainan bak pasir pada anak kelompok A di RA Al-Ishlah Kalipare Kecamatan Kalipare Kabupaten Malang.

Berasarkan hasil penelitian tersebut dan dari hasil observasi keseluruhan pada siklus I dan siklus II dapat meningkatkan kreativitas seni anak kelompok A di 
RA Al-Ishlah Kalipare melalui permainan bak pasir. Hal ini dapat dilihat dari pencapaian persentase keseluruhan yang dihitung pada siklus I 37,49\% pada siklus II meningkat dengan persentase $85,71 \%$. 2) Penerapan permainan bak pasir di RA Al-Ishlah Kalipare sebagai berikut: a) Guru menjelaskan aturan bermain bahwa dalam permainan bak pasir ini pasir tidak boleh dihambur-hamburkan terutama pada teman, setelah bermain alat yang telah digunakan dibereskan dan dilanjutkan mencuci tangan. Lalu guru mencontohkan cara bermain permainan bak pasir, yaitu dengan mengambil sedikit demi sedikit pasir untuk dimasukkan pada cetakan sambil dipadatkan hingga penuh, kemudian di cetak pada wadah yang telah disediakan. dilanjutkan anak mencoba mencetak dengan 1 bentuk cetakan yang telah disiapkan oleh guru. 2) Anak dibagi menjadi dua kelompok. Kelompok pertama mendapat cetakan binatang dan kelompok kedua mendapat cetakan geometri. Guru menjelaskan bahan, alat dan aturan bermain serta mencontohkan cara bermain permainan bak pasir. Anak diberi kesempatan untuk bertanya tentang kegiatan bermain bak pasir. guru mempersilahkan anak untuk bermain permainan bak pasir sesuai dengan ide kreatif anak masing-masing. Anak secara bergantian menceritakan hasil dari karya seni yang dibuatkan menggunakan cetakan. Setelah selesai bermain guru mengajak anak untuk membereskan kembali alat-alat permainan yang telah dipakai.

Berikut ini beberapa saran bagi guru dan lembaga: 1) Guru diharapkan kreatif dalam memilih media dan kegiatan untuk menunjang keberhasilan dalam pembelajaran. 2) Guru dalam memilih media pembelajaran yang menyenangkan dan menarik untuk anak. 3) Guru diharapkan memiliki pengetahuan tentang tumbuh kembang anak agar dalam kegiatan pembelajaran sesuai dengan kemampuan dan tepat dengan tahap perkembangan anak. 4) Sekolah diharapkan menyediakan fasilitas permainan dan media lainnya dengan tujuan untuk mendukung berjalannya kegiatan belajar mengajar.

\section{DAFTAR RUJUKAN}

Fadilillah, M (2017). Bermain dan Permainan. Cetakan I. Jakarta: Kencana.

Fadilillah, M., (2014). Desain Pembelajaran PAUD. Cetakan I. Jogjakarta: ArRuzz Media

Halimah, L., (2016). Pengembangan Kurikulum Pendidikan Anak usia Dini. Cetakan I. Bandung: PT. Refika Aditama

Hurlock, Elizabeth., B. (1989). Perkembangan Anak. Jilid I. Jakarta: Erlangga

Kasbolah, K., (1998). Penelitian Tindakan Kelas. Jakarta: Departemen Pendidikan dan Kebudayaan.

Kustandi, C., (2013). Media Pembelajaran Manusia dan Digital. Bogor: Ghali Indonesia. 
Kusumah, Wijaya dan Dedi Dwitagama. (2011). Mengenal Penelitian Tindakan Kelas. Jakarta: Indeks.

Majidi (2017). Pendidikan Anak Usia Dini: Konsep dan Teori. Jakarta: PT. Bumi Aksara.

Mansur (2014). Pendidikan Usia Dini Dalam Islam. Jakarta: Pustaka Pelajar.

Mulyani, Novi (2017). Pengembangan Seni Anak Usia Dini. Bandung: PT. Remaja Rosdakarya. 